\title{
Cadmium toxicity on the freshwater microalga Chlamydomonas moewusii Gerloff: Biosynthesis of thiol compounds
}

Cristina Suárez, Enrique Torres, Mónica Pérez-Rama, Concepción Herrero, Julio Abalde

Laboratorio de Microbiología, Facultad de Ciencias, Universidade da Coruña, 15008. A Coruña, Spain

Environmental Toxicology and Chemistry, Volume 29, Issue 9, September 2010 Submitted 16 February 2009; Returned for Revision 16 February 2010; Accepted 19 March 2010

This is the peer reviewed version of the following article:

Suárez, C., Torres, E., Pérez-Rama, M., Herrero, C. and Abalde, J. (2010), Cadmium toxicity on the freshwater microalga Chlamydomonas moewusii Gerloff: Biosynthesis of thiol compounds. Environmental Toxicology and Chemistry, 29: 2009-2015. doi:10.1002/etc.242

which has been published in final form at http://dx.doi.org/10.1002/etc.242 . This article may be used for non-commercial purposes in accordance with Wiley Terms and Conditions for Self-Archiving.

\footnotetext{
Abstract

Cadmium (Cd) toxicity and production of different thiols (phytochelatins, glutathione, $\gamma$-Glu-Cys and cysteine) were studied in the microalga Chlamydomonas moewusii exposed to different concentrations of this metal $(1,2,4,6,8$, and $10 \mathrm{mg} / \mathrm{L})$ for $96 \mathrm{~h}$. The inhibitory effect of $\mathrm{Cd}$ on growth was demonstrated. The value of EC50 (metal concentration which reduces the population growth to 50\% of the control) obtained for this microalga was estimated at $4.1 \pm 0.8 \mathrm{mg} / \mathrm{L}$ of $\mathrm{Cd}$ after $96 \mathrm{~h}$ of exposure. The amount of thiol compounds synthesized by $C$. moewusii changed with $\mathrm{Cd}$ concentration. Cysteine concentrations were significantly higher compared to those of $\gamma$-Glu-Cys and glutathione in all the $\mathrm{Cd}$ concentrations assayed. The amino acid cysteine reached its higher levels in those cultures in which a decrease in the
} 
concentration of phytochelatins (PCs) was observed. Both cysteine and glutathione concentrations showed significant differences along the $\mathrm{Cd}$ concentrations assayed, while the amount of $\gamma$-Glu-Cys detected remained stable. The PCs detected were of two, three, and four subunits. The level of $\mathrm{PC}_{2}$ was higher than that of $\mathrm{PC}_{3}$ and $\mathrm{PC}_{4} . \mathrm{PC}_{4}$ was detected only in the cultures exposed to the Cd concentrations of 1 and $2 \mathrm{mg} / \mathrm{L}$, in which the synthesis of phytochelatins was higher. A rapid increase in the production of $\mathrm{PC}_{2}$ and $\mathrm{PC}_{3}$ was observed up to a Cd concentration of $2 \mathrm{mg} / \mathrm{L}$, after which their levels began to decrease. Phytochelatins were not detected in cultures without $\mathrm{Cd}$ (controls) and in those exposed to the maximum Cd concentration $(10 \mathrm{mg} / \mathrm{L})$, in which cell growth was completely inhibited

\section{Keywords}

Thiols; Phytochelatins; Cadmium; Chlamydomonas moewusii; Toxicity

\section{INTRODUCTION}

Widespread pollution by heavy metals that is generated by human activities has serious effects on human health and the environment. Heavy metals are among the most toxic pollutants that affect the survival of aquatic organisms. This is because, unlike other pollutants (weed-killers, pesticides), they remain in the environment without degradation. Therefore, they accumulate in sediments and can be released slowly into the water, exercising their toxicity even in the long term. In addition, metals accumulate along the food chain, causing a serious threat to human health [1]. In particular, $\mathrm{Cd}$ is one of the most dangerous heavy metals present in ecosystems, which causes their deterioration. It affects, in various ways, all organisms in the environment, including microalgae. The damaging effects of $\mathrm{Cd}$ on microalgae are of particular significance considering the essential role played by these photoautotrophic microorganisms as primary producers and initial link in the food chain.

The presence of $\mathrm{Cd}$ in the environment is increasing due to its use in industrial processes [2]; it is a common industrial pollutant. Because of this increase, microalgae have developed different tolerance mechanisms to try to counteract its toxicity. One of the most common responses to $\mathrm{Cd}$ stress by microalgae is the production of thiol compounds [3]. Phytochelatins (PCs: small, thiol-containing peptides) are one of the most important thiol compounds synthesized against this stress. Phytochelatins have the amino acid structure $(\gamma \text {-Glu-Cys })_{\mathrm{n}}-$ Gly, where $n$ ranges from 2 to 11 . They are structurally related to the tripeptide glutathione (GSH; $\gamma$-Glu-Cys-Gly). Several physiological, biochemical, and genetic studies have confirmed that GSH (or related 
compounds) is the substratum to the PCs biosynthesis [4, 5]. Tripeptide glutathione acts as the base unit of PCs. At the same time, the amino acid cysteine is the main precursor of GSH via synthesis of $\gamma$-Glu-Cys. The biosynthesis of cysteine is required under conditions of metal stress to allow the increase in the biosynthesis of GSH and PCs [3]. Different reports have shown that cysteine is also involved in metal detoxification [6].

Phytochelatins are synthesized enzymatically from the GSH in a sequential two-step reaction, by the enzyme $\gamma$-glutamyl-cysteinyl-dipeptidyl transpeptidase (phytochelatin synthase) [7]. This enzyme catalyzes the reaction by which the oligomer grows by the addition of $\gamma$-glutamyl-cysteinyl-dipeptidyl ( $\gamma$-Glu-Cys) molecules to the phytochelatin peptide chain. This dipeptide is derived from GSH. Genes for this enzyme have been isolated from Schizosaccharomyces pombe, wheat, and Arabidopsis thaliana [8].

The main property of PCs is their ability to chelate metals intracellularly, playing an important role in metal tolerance [9]. The role of PCs in $\mathrm{Cd}^{2+}$ detoxification has been established by showing that $S$. pombe and A. thalianamutants, lacking synthesis of PCs or GSH, are $\mathrm{Cd}^{2+}$ sensitive [10]. Compared to metallothioneins (MTs), PCs offer many advantages that are due to their unique structural characteristics. Their metal-binding capacity is higher than that of MTs; in addition, PCs can incorporate high levels of inorganic sulfide, which results in very significant increases in the $\mathrm{Cd}^{2+}$-binding capacity of these peptides [11]. The complex formed between PCs and $\mathrm{Cd}^{2+}$ occurs through coordination with the sulfhydryl group of the cysteine, forming thiolate-metal complexes. This complex chelates the metal in the cytosol of the cell, and therefore it is inactivated. This avoids the inhibitory effects of the metal on active catalytic sites or on structural proteins [5]. Once $\mathrm{Cd}^{2+}$ is chelated by PCs, these complexes are carried toward the vacuolar system. This metal-chelating ability is an argument in favor of their role in metal tolerance [12].

Cadmium is the main inductor of PC synthesis, although synthesis of PCs has also been reported in algae exposed to high concentrations of $\mathrm{Cu}$ [13] and $\mathrm{Zn}$ [14]. However, Tripathi et al. [15] observed that the level of total thiols in Scenedesmus sp. substantially declined during both short- and long-term exposure to $\mathrm{Cu}$ and $\mathrm{Zn}$, and therefore phytochelatins seemed not to be of much importance in conferring tolerance to Scenedesmus sp. against metal-induced oxidative stress. In the same way, Tsuji et al. [14] observed that phytochelatins enhanced the tolerance of Dunaliella tertiolecta against metal-induced oxidative stress but only when the GSH level was not depleted in the cells.

The objectives of the present study were to examine Cd toxicity on the freshwater microalga Chlamydomonas moewusii Gerloff and to study the capacity of this microalga to synthesize PCs in presence of this metal. Besides the study of PCs synthesis, the 
concentrations of cysteine, $\gamma$-Glu-Cys, and GSH were also measured in response to different $\mathrm{Cd}^{2+}$ concentrations.

Chlamydomonas moewusii Gerloff is an unicellular green freshwater microalga from the family Chlamydomonaceae. This microalga has been used in toxicological studies with herbicides [16] and is an important organism model for cytological studies. Therefore, it is also interesting to know its response to metals, especially to $\mathrm{Cd}^{2+}$, which is one of the most toxic heavy metals and inducer of PCs. The role of PCs (and related molecules) in tolerance to $\mathrm{Cd}$ is discussed in this paper.

\section{MATERIALS AND METHODS}

Test organism and culture condition

The microalga species chosen for this study was Chlamydomonas moewusiiGerloff (Chlamydomonadaceae). This strain was obtained from the CCAP Culture Collection of Algae and Protozoa of Freshwater Ecology Institute (Cumbria, UK) (strain CCAP $11 / 5 \mathrm{~B})$. It was grown and maintained in autoclaved $\left(121^{\circ} \mathrm{C}, 20 \mathrm{~min}\right)$ Bristol medium [17]. Microalgal cultures were incubated at a temperature of $18 \pm 1^{\circ} \mathrm{C}$, illuminated with $68.25 \mu \mathrm{mol}$ photon $/\left(\mathrm{m}^{2} \mathrm{~s}\right)$, with a dark:light cycle of $12: 12 \mathrm{~h}$ and continuously aerated with a constant flux of $10 \mathrm{~L} / \mathrm{min}$. All experiments were performed with this culture medium.

\section{Chemicals and reagents}

All chemicals were of the highest purity available. Cd chloride $2 \frac{1}{1 / 2}$-hydrate $\left(\mathrm{CdCl}_{2} .2\right.$ $\left.1 / 2 \mathrm{H}_{2} \mathrm{O}\right)$, orthophosphoric acid $\left(\mathrm{H}_{3} \mathrm{PO}_{4}\right)$, boric acid $\left(\mathrm{H}_{3} \mathrm{BO}_{3}\right)$, hydrochloric acid $(\mathrm{HCl})$, sodium hydroxide $(\mathrm{NaOH})$, monobromobimane $\left(\mathrm{C}_{10} \mathrm{H}_{11} \mathrm{~N}_{2} \mathrm{O}_{2} \mathrm{Br}\right)$, sodium borohydride $\left(\mathrm{NaBH}_{4}\right)$, diethylenetriaminetetraacetic acid anhydride $\left(\mathrm{C}_{14} \mathrm{H}_{19} \mathrm{~N}_{3} \mathrm{O}_{8}\right)$, ethylenediaminetetraacetic acid (EDTA), lugol and Tris (hydroxymethyl) amino methane (TRIS) were purchased from Sigma. High-performance liquid chromatography-grade methanol was purchased from Scharlau Chemie. Filters were obtained from Millipore (Millipore Ibérica). The different reagents and buffers were prepared with Milli-Q ${ }^{\circledR}$ water obtained from a Milli Q Plus system (Millipore Ibérica).

\section{Cadmium stock}

A stock solution of $\mathrm{Cd}$ was prepared by dilution of cadmium chloride $2 \frac{1}{2} 2$ - hydrate

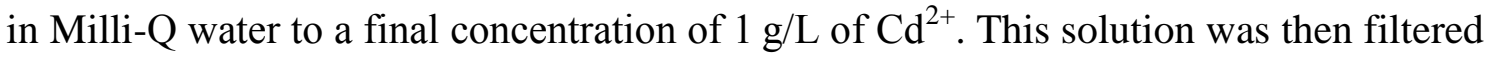
through a $0.22 \mu \mathrm{m}$ Millipore filter. 


\section{Experiment design and metal treatment}

The test cultures were grown in sterilized $1000 \mathrm{ml}$ Pyrex glass bottles. For the experiments, appropriated volumes $(1,2,4,6,8$ and $10 \mathrm{ml})$ of the $\mathrm{Cd}^{2+}$ stock solution were added to a final volume of $1 \mathrm{~L}$ of culture medium to obtain $\mathrm{Cd}$ concentrations of 1 , $2,4,6,8$, and $10 \mathrm{mg} / \mathrm{L}$, respectively. Inocula for all experiments were taken from a culture in logarithmic phase. Each inoculum was added to each culture medium, containing each one of the different $\mathrm{Cd}$ concentrations assayed, yielding an initial cell density of $40 \times 10^{4}$ cells $/ \mathrm{ml}$. Control cultures without $\mathrm{Cd}^{2+}$ were also included. All cultures were performed in triplicate and were kept for $96 \mathrm{~h}$.

\section{Growth measurement}

Growth of microalgal cultures was measured daily by counting culture aliquots in a Neubauer (Blaubrand) hemocytometer chamber after fixation with lugol. The degree of growth inhibition by $\mathrm{Cd}$ in $C$. moewusii cells was measured during the $96 \mathrm{~h}$ of culture. Total cells present in a known volume of culture were counted and then cell density was calculated. The $\mathrm{Cd}^{2+}$ concentration that reduces the population growth to $50 \%$ of the control growth level (EC50) was calculated using a log dose-response curve. Analysis of the data was conducted by applying a nonlinear regression to log metal concentration versus the difference, respect to the control, of the final cell densities obtained after $96 \mathrm{~h}$ of culture. These analyses were performed using SigmaPlot 9.01 software package (Systat Software). The EC50 was calculated from the regression equation. Logistic equation of four parameters was chosen for its goodness-of-fit [18].

The growth rate $(\mu)$, expressed as $1 / \mathrm{d}$, was obtained from the following equation:

$$
\mu=\left[\ln \left(\mathrm{N}_{\mathrm{t}}\right)-\ln \left(\mathrm{N}_{0}\right)\right] /\left[\ln 2\left(t-t_{0}\right)\right]
$$

where $t_{0}$ and $t$ are the initial and final time of the exponential growth period, both expressed as days, and $\mathrm{N}_{0}$ and $\mathrm{N} t$ are the number of cells/ml at those times.

Characterization and quantification of cadmium-induced thiols

Chlamydomonas moewusii cells were harvested by centrifugation (1500 $\mathrm{g}$ for $10 \mathrm{~min}$ ) from a certain volume of each culture after $96 \mathrm{~h}$ of growth, and stored at $-20^{\circ} \mathrm{C}$ until the analysis. Thiol peptides were then extracted from the frozen samples and derivatized with monobromobimane $(\mathrm{mBrB})$ that specifically labels sulfhydrylcontaining compounds [19]. 
A capillary electrophoresis technique was used to measure GSH, $\gamma$-Glu-Cys, the amino acid cysteine, and PCs previously derivatized with the monobromobimane [19]. Using this technique, all the thiols mentioned previously could be analyzed in the same run. The equipment used was an $\mathrm{HP}^{3 \mathrm{D}} \mathrm{CE}$ (Capillary Electrophoresis System; Agilent Technologies) and the electropherograms were analyzed with the Agilent ChemStation Software (Agilent Technologies). Standards of PCs, cysteine, $\gamma$-Glu-Cys, and GSH, derivatized in the same way as the biological samples, were used to identify the different peaks.

Data analysis

Data were expressed as means \pm standard error. All data were analyzed using the statistical program SPSS 12.0 (SPSS Iberica, Madrid, Spain). The results for the effect of $\mathrm{Cd}^{2+}$ on microalgal growth and for the different thiols production were tested by oneway analysis of variance (ANOVA). Finally, data were compared with the Dunnett test. The $\alpha$-level for significant differences was set at $p<0.05$.

\section{RESULTS}

Cadmium effect

\section{Chlamydomonas moewusii}

Cultures of $C$. moewusii exposed to different $\mathrm{Cd}^{2+}$ concentrations $(1,2,4,6,8$ and $10 \mathrm{mg} / \mathrm{L}$ ) showed significant differences in their growth (Fig. 1) as a result of the toxic effect of the metal. The ANOVA test $(p<0.05)$ revealed a significant effect of $\mathrm{Cd}^{2+}$ on the growth of $C$. moewusii after $96 \mathrm{~h}$ of exposure. This inhibitory effect was directly proportional to metal concentration. Even at $24 \mathrm{~h}$ of culture, differences in the growth among the cultures were detected. Those differences became larger as time of exposure increased. This observation proved the inhibitory effect of $\mathrm{Cd}^{2+}$ in the growth of this microalga. Cultures with $\mathrm{Cd}^{2+}$ concentrations of 6 and $8 \mathrm{mg} \mathrm{Cd} / \mathrm{L}$ hardly grew, and in those with the highest $\mathrm{Cd}^{2+}$ concentration assayed $(10 \mathrm{mg} / \mathrm{L})$, total inhibition of growth was observed. The cellular density of the cultures with higher $\mathrm{Cd}^{2+}$ concentrations did not vary throughout the $96 \mathrm{~h}$ of culture.

The statistical analysis, applying the Dunnett test to the values of the cellular density reached after $96 \mathrm{~h}$ of exposure, showed that the toxic effect of the different $\mathrm{Cd}^{2+}$ concentrations assayed on $C$. moewusii growth could be expressed as $0<1<2<4<6<8=10$ (Fig. 1). From this sequence, it is possible to deduce that the lowest observed effect concentration (LOEC) obtained in this study was $1 \mathrm{mg} \mathrm{Cd} / \mathrm{L}$. The no 
observed effect concentration (NOEC) was not observed in this assay, or it can be considered the control culture $(0 \mathrm{mg} \mathrm{Cd} / \mathrm{L})$.

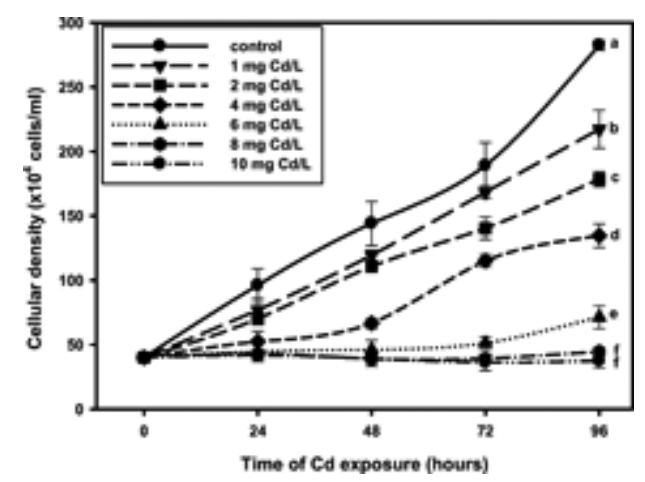

Figure 1. Growth of C.moewusii cells with the $\mathrm{Cd}^{2+}$ concentrations assayed. Each data point represents mean \pm standard error of 3 replicates. Data points marked with the same letter are not significantly different.

The data of the growth rate obtained for the cultures exposed to the different $\mathrm{Cd}^{2+}$ concentrations assayed, also proved the toxic effect of $\mathrm{Cd}^{2+}$ on the growth of this microalga, since this value decreased as the $\mathrm{Cd}^{2+}$ concentration increased (Table 1). The ANOVA test $(p<0.05)$ applied to the growth rates confirmed this significant effect of the metal, and the data obtained using the Dunnett test showed that this toxic effect could be expressed as $0>1>2>4>6>8=10$ (Table 1 ). These results, both for the cellular density at $96 \mathrm{~h}$ of growth and for the growth rates, showed that the toxic effect of $\mathrm{Cd}^{2+}$ was evident between each pair of $\mathrm{Cd}^{2+}$ concentrations, except those with 8 and $10 \mathrm{mg} \mathrm{Cd} / \mathrm{L}$, in which the total inhibition of the growth was observed.

Table 1. Growth rate \pm standard error (1/d) of Chlamydomonas moewusiicultures exposed to different $\mathrm{Cd}^{2+}$ concentrations after $96 \mathrm{~h}$. Data marked with asterisks are not significantly different.

Cadmium concentration (mg/L)

\begin{tabular}{ccccccc}
\hline control & 1 & 2 & 4 & 6 & 8 & 10 \\
\hline $0.70 \pm 0.01$ & $0.61 \pm 0.02$ & $0.54 \pm 0.01$ & $0.44 \pm 0.02$ & $0.21 \pm 0.04$ & $0.04 \pm 0.004 *$ & 0 \\
\hline
\end{tabular}

Dose-response curves are useful to describe a toxic action in relation with the conditions of the experiment. Thus, Figure 2 shows the dose-response curve for the growth of $C$. moewusii, and the EC50 was calculated from the regression equation applied. The toxic effect of $\mathrm{Cd}^{2+}$ can be also measured directly through this parameter. The value of the median effective concentration (EC50) for C. moewusii was estimated at $4.1 \pm 0.8 \mathrm{mg} / \mathrm{L}$ of $\mathrm{Cd}^{2+}$ after $96 \mathrm{~h}$ of exposure to the metal. 


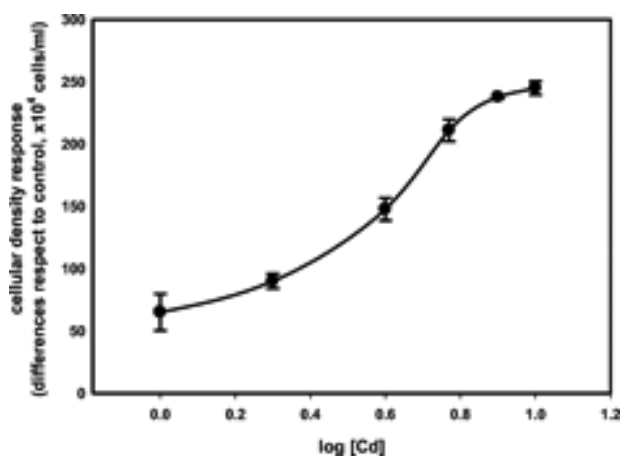

Figure 2. Dose - response curve for the growth of $C$. moewusii after $96 \mathrm{~h}$ of exposure to the different $\mathrm{Cd}^{2+}$ concentrations. Each data point represents mean \pm standard error of 3 replicates.

\section{Glutathione, cysteine, and $\gamma$-Glu-Cys production}

Figure 3 shows the concentration of cysteine, $\gamma$-Glu-Cys and glutathione reached in the different cultures of $C$. moewusii exposed to different $\mathrm{Cd}^{2+}$ concentrations and in cultures without metal addition after $96 \mathrm{~h}$ of exposure. The synthesis of the amino acid cysteine depended on the $\mathrm{Cd}^{2+}$ concentration added to the medium. A great increase in the cysteine concentration was observed after $96 \mathrm{~h}$ of culture in C. moewusii cells exposed to $\mathrm{Cd}^{2+}$. The amount of cysteine in all the $\mathrm{Cd}^{2+}$ concentrations assayed was significantly higher than that of glutathione and $\gamma$-Glu-Cys $(p<0.05)$. A significant increase was observed in cysteine content of the cells as $\mathrm{Cd}^{2+}$ concentration increased up to $4 \mathrm{mg} / \mathrm{L}$. The amount of cysteine remained with no significant variations $(p>0.05)$ among the $\mathrm{Cd}^{2+}$ concentrations of 4 and $8 \mathrm{mg} / \mathrm{L}$, in which it reached its highest value. At $10 \mathrm{mg} / \mathrm{L}$ of $\mathrm{Cd}^{2+}$, an important reduction in the cysteine concentration took place, reaching only a value of $68 \pm 8.79 \mathrm{amol} / \mathrm{cell}$, even lower than in the control cultures. Thus, the ANOVA test showed significant differences in the cysteine levels between the different $\mathrm{Cd}^{2+}$ concentrations $(p<0.05)$. In addition, the statistical analysis using the Dunnett test showed that these differences in the cysteine production are significant among all the $\mathrm{Cd}^{2+}$ concentrations assayed except those with 4,6 and $8 \mathrm{mg} \mathrm{Cd} / \mathrm{L}$, in which the higher levels of cysteine reached were not significantly different. 


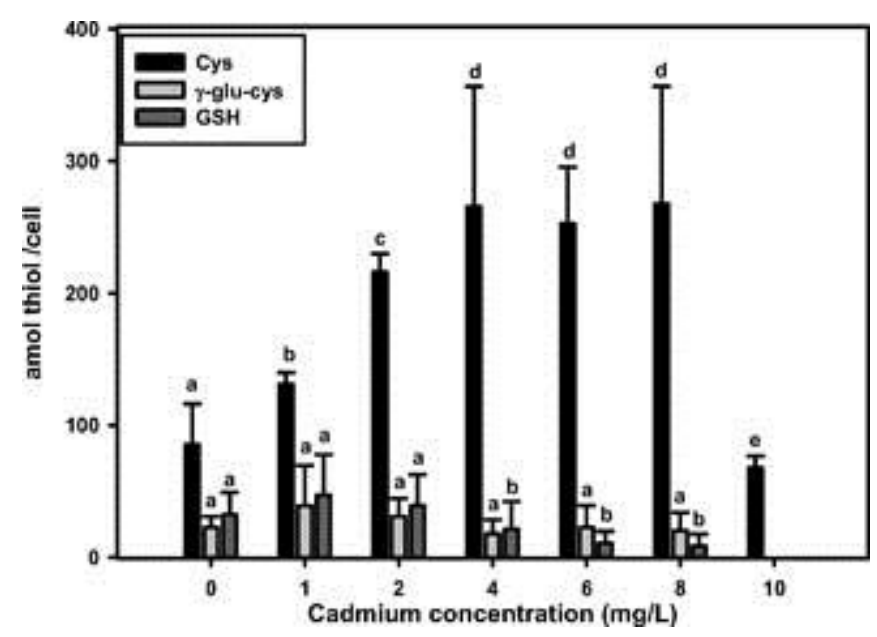

Figure 3. Production of glutathione (GSH), $\gamma$-glutamylcysteine ( $\gamma$-EC), and the amino acid cysteine in Chlamydomonas moewusii cells in response to different $\mathrm{Cd}^{2+}$ concentrations expressed as amol thiol/cell (where $\mathrm{a}=10^{-18}$ ), after $96 \mathrm{~h}$ of exposure. Data bars represent mean \pm standard error of 3 replicates. Data bars marked with the same letter are not significantly different.

The concentrations of GSH and $\gamma$-Glu-Cys observed were very low compared with the values of the amino acid cysteine achieved. The statistical analysis for GSH, using the ANOVA test, showed that the synthesis of this low-molecular-weight thiol presented significant changes along the $\mathrm{Cd}^{2+}$ concentrations tested $(p<0.05)$, except for that of $10 \mathrm{mg} \mathrm{Cd} / \mathrm{L}$, in which both $\mathrm{GSH}$ and $\gamma$-Glu-Cys were not detected. A slight decrease in the GSH levels along the $\mathrm{Cd}^{2+}$ concentrations assayed is also observed in the Figure 3. The amount of GSH decreased as the cysteine level increased. The highest amount of GSH was detected in the culture with $1 \mathrm{mg} / \mathrm{L}$ of $\mathrm{Cd}^{2+}$, with a value of $47.1 \pm 30.27 \mathrm{amol} / \mathrm{cell}$. However, $\gamma$-Glu-Cys did not present significant differences in its levels along the $\mathrm{Cd}^{2+}$ concentrations assayed $(p>0.05)$. Nevertheless, the values of cysteine observed in all the $\mathrm{Cd}^{2+}$ concentrations assayed were much higher than those of GSH and $\gamma$-Glu-Cys.

\section{Cadmium effect on PCs production}

In the present study, the synthesis of PCs of two, three and four subunits $\left((\gamma-\mathrm{EC})_{2} \mathrm{G}\right.$, $(\gamma-\mathrm{EC})_{3} \mathrm{G}$ and $\left.\left.(\gamma-\mathrm{EC})_{4} \mathrm{G}\right)\right)$ in response to the exposure of $C$. moewusii to $\mathrm{Cd}^{2+}$ was detected (Fig. 4). The synthesis of these PCs was not detected in the control cultures with the applied technique. 


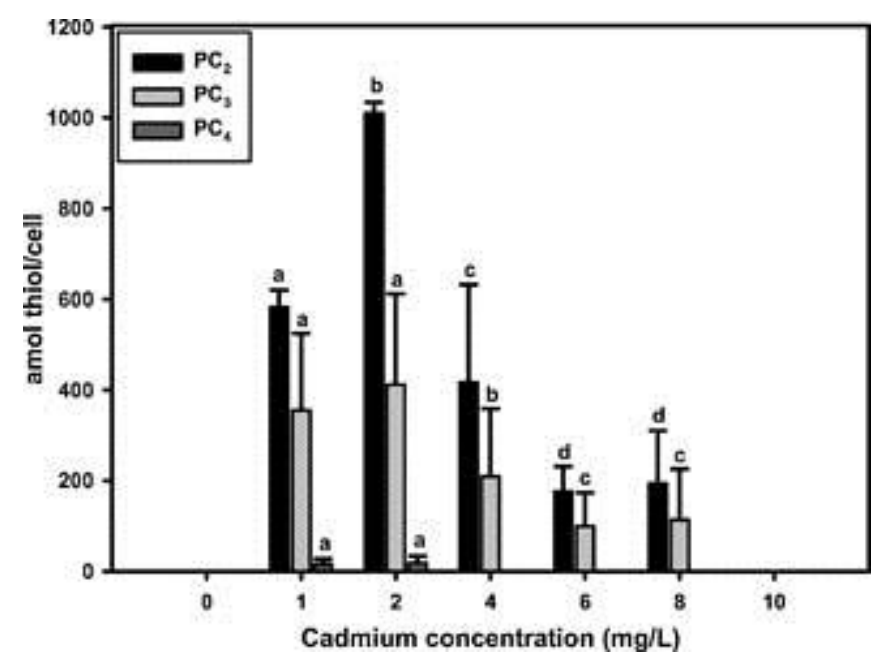

Figure 4. Production of phytochelatins in Chlamydomonas moewusii cells in response to different $\mathrm{Cd}^{2+}$ concentrations, expressed as amol thiol/cell (where $\mathrm{a}=10^{-18}$ ), after $96 \mathrm{~h}$ of exposure. Data bars represent mean \pm standard error of 3 replicates. Data bars marked with the same letter are not significantly different.

In relation to $\mathrm{PC}_{4}$, it was only detected in the cultures in which the highest synthesis of PCs occurred ( 1 and $2 \mathrm{mg} / \mathrm{L}$ of $\mathrm{Cd}^{2+}$ ), but the concentration of $\mathrm{PC}_{4}$ observed was much lower than that of $\mathrm{PC}_{2}$ and $\mathrm{PC}_{3}$.

The concentration of $\mathrm{PC}_{2}$ was much higher than that of $\mathrm{PC}_{3}$ in all the cultures where they were detected, but both PCs followed the same evolution along the different $\mathrm{Cd}^{2+}$ concentrations assayed. Their levels increased until the cultures exposed to $2 \mathrm{mg} / \mathrm{L}$ of $\mathrm{Cd}^{2+}$ in which they reached their maximum values $(1010 \pm 23.44 \mathrm{amol} / \mathrm{cell}$ and $411 \pm 170 \mathrm{amol} / \mathrm{cell}$, respectively). In higher $\mathrm{Cd}^{2+}$ concentrations, the levels of PCs decreased significantly until the concentration of $8 \mathrm{mg} \mathrm{Cd}^{2+} / \mathrm{L}$. They were not detected in the cultures exposed to $10 \mathrm{mg} / \mathrm{L}$ of $\mathrm{Cd}^{2+}$, in which the growth cell was completely inhibited.

\section{DISCUSSION}

It is well recognized that $\mathrm{Cd}$ is classified as one of the most dangerous metals, with a severe toxicity for both aquatic and land organisms 2 . This is the reason why this metal has been chosen for this study. Chlamydomonas moewusii is frequently studied in laboratory bioassays, but few data on Cd toxicity and tolerance are available for this species. With respect to cell growth, $C$. moewusii is a species with a high tolerance to $\mathrm{Cd}$, whose total inhibition is achieved only at concentrations higher than $8 \mathrm{mg} \mathrm{Cd}^{2+} / \mathrm{L}$.

Growth inhibition is a common symptom of Cd toxicity, but many studies have shown that there is a wide range of sensitivity to $\mathrm{Cd}^{2+}$ among microalgal species. These 
differences occur even within species of the same genus. This happens, for example, between Tetraselmis gracilis with an EC50 value of $1.8 \mathrm{mg} \mathrm{Cd} / \mathrm{L}$ [20] and Tetraselmis suecica with an EC50 of $7.9 \mathrm{mg} \mathrm{Cd} / \mathrm{L}$ after $144 \mathrm{~h}$ of exposure [21]. Marine microalgae are among the organisms that tolerate higher $\mathrm{Cd}^{2+}$ concentrations. The growth of Chlorococcum sp. and Tetraselmis gracilis is inhibited at concentrations of 2.5 to 3 and $5 \mathrm{mg} / \mathrm{L}$ of $\mathrm{Cd}^{2+}$, respectively [20], which also indicates a high resistance to $\mathrm{Cd}^{2+}$. Folgar et al. [22] demonstrated that Dunaliella salina is one of the other most tolerant species to this metal. It tolerated a Cd concentration as high as $40 \mathrm{mg} \mathrm{Cd}{ }^{2+} / \mathrm{L}$ along $96 \mathrm{~h}$ of culture, and the EC50 value obtained was $48.9 \mathrm{mg} \mathrm{Cd} / \mathrm{L}$. However, a study was performed by Visviki and Rachlin [23] in which the EC50 obtained for the same microalga was much lower, although the culture conditions were completely different.

Contrary to these highly tolerant microalgal species, other species are very sensitive to $\mathrm{Cd}^{2+}$, such as Asterionella formosa, whose growth is inhibited at concentrations of $0.01 \mu \mathrm{g} / \mathrm{L}$ of this metal [24]. The EC50 value obtained for the microalga Isochrysis galbana after $96 \mathrm{~h}$ of exposure was $0.74 \mathrm{mg} \mathrm{Cd} / \mathrm{L} \mathrm{[25].}$

Many studies have demonstrated that freshwater microalgae are generally more sensitive to $\mathrm{Cd}^{2+}$ than marine microalgae. Thus, for Chlorella sp., growth is inhibited with a concentration of $1.12 \mathrm{mg} / \mathrm{L}$ of $\mathrm{Cd}^{2+}$, with a $\mathrm{LD} 50$ of $0.34 \mathrm{mg} / \mathrm{L}$ at $72 \mathrm{~h}$ of culture [26]. For Scenedesmus vacuolatus, the growth rate was still optimal at a $\mathrm{Cd}^{2+}$ concentration of $0.12 \mu \mathrm{g} / \mathrm{L}$ [27]. However, Mosulen et al. [28] found that $\mathrm{Cd}^{2+}$ ions are toxic for the growth ofChlamydomonasreinhardtii at a concentration of $33.7 \mathrm{mg} / \mathrm{L}$ after $96 \mathrm{~h}$ of culture. Likewise, Kobayashi et al. [29] also observed that $C$. reinhardtii $\mathrm{CC} 125$ cells could grow in medium containing up to $14 \mathrm{mg} \mathrm{Cd} / \mathrm{L}$.

The EC50 obtained in the present study for $C$. moewusii was estimated at $4.1 \pm 0.8 \mathrm{mg} / \mathrm{L}$ of $\mathrm{Cd}^{2+}$ after $96 \mathrm{~h}$ of exposure. Because of this high value, it was necessary to expose the microalga to high $\mathrm{Cd}^{2+}$ concentrations to reach complete inhibition of growth. It was exposed to a maximum $\mathrm{Cd}^{2+}$ concentration of $10 \mathrm{mg} / \mathrm{L}$, although growth inhibition was already observed at a $\mathrm{Cd}^{2+}$ concentration of $8 \mathrm{mg} / \mathrm{L}$ (Fig. 1).

Although this EC50 value is lower than that obtained for $C$. reinhardtii [28, 29], when it is compared with the values obtained for other freshwater microalgae, it can be concluded that $C$. moewusii is a microalga very tolerant to $\mathrm{Cd}^{2+}$ ions. Thus, considering the efficiency for metal removal that microalgal cells have [30], this microalga could be used as a good organism to remove high amounts of this metal from the environment. Based on these growth traits, it is suggested that $C$. moewusii has a potential in bioremediation of Cd-contaminated waters, because tolerance to metal toxicity is a crucial feature for accumulators. 
The natural concentration of $\mathrm{Cd}$ in the environment is very low (usually less than $0.5 \mu \mathrm{g} / \mathrm{L}$ in clean water), but industrial development requires an increase in its use, which leads to higher levels of this metal in aquatic environments, causing their deterioration 2. Microalgae are directly exposed to this pollution and therefore must develop tolerance mechanisms. Several mechanisms are known that allow these microorganisms to develop protection against high levels of $\mathrm{Cd}$, being the intracellular ones, some of the most studied. Within this group, phytochelatins stand out. Several studies have demonstrated that $\mathrm{Cd}^{2+}$ is one of the most powerful inductors of PC biosynthesis. Because of this, PCs have been the mechanism of defense most investigated with regard to $\mathrm{Cd}^{2+}$ tolerance $[4,31]$.

For example, Alvarez-Legorreta et al. [32] observed that in the seagrassThalassia testudinum, all tissues tested (green blades, live sheaths and root/rhizomes) experienced an increase in thiol-containing compounds after $144 \mathrm{~h}$, as a response to $\mathrm{Cd}^{2+}$ exposure, with $\mathrm{PC}_{2}$ reaching the highest values. This $\mathrm{PC}$ synthesis showed a significant positive correlation with respect to $\mathrm{Cd}^{2+}$ exposure. Like the results obtained by these authors, the present study also found that the PC synthesized in higher amount by $C$. moewusii was $\mathrm{PC}_{2}$. Synthesized PCs bind $\mathrm{Cd}^{2+}$ to form the complex $\mathrm{PC}-\mathrm{Cd}^{2+}$. In this complex, $\mathrm{Cd}^{2+}$ is bound to $-\mathrm{SH}$ groups of these molecules [26]. There are many studies that show that PCs are the main intracellular metal chelators induced by $\mathrm{Cd}^{2+}$ treatments; in fact, it was observed that PC complexes sequestered more than $70 \%$ of the total $\mathrm{Cd}^{2+}$ found in cells treated with this metal [33]. It was also observed that $T$. suecica synthesized PCs in cultures with a $\mathrm{Cd}^{2+}$ concentration of $6 \mathrm{mg} / \mathrm{L}$, and about $87 \%$ of the accumulated $\mathrm{Cd}^{2+}$ was bound by these molecules [34]. Furthermore, it has been proposed that the synthesis of short chain PCs is the result of a relatively low-level heavy metal exposure, whereas the synthesis of long chain PCs presumably is caused by exposure to high heavy metal levels [35]. In the present study with $C$. moewusii, a significant increase of PCs of 2 and 3 subunits was also observed, reaching high levels in the cultures exposed to $\mathrm{Cd}^{2+}$ until a concentration of $8 \mathrm{mg} \mathrm{Cd} / \mathrm{L}$. Phytochelatins of four subunits were also detected, but it was only observed in the cultures exposed to 1 and $2 \mathrm{mg} \mathrm{Cd} / \mathrm{L}$. The concentration reached was very low. It is noteworthy that the amounts of $\mathrm{PC}_{2}$ and $\mathrm{PC}_{3}$ increased until the $\mathrm{Cd}^{2+}$ concentration approached the obtained EC50 value. At higher $\mathrm{Cd}^{2+}$ concentrations, the amounts of these PCs began to decrease, which reveals their role as a mechanism of tolerance to $\mathrm{Cd}^{2+}$ developed by this microalga. In fact, at these metal concentrations, the growth of $C$. moewusii showed an important reduction (Table 1).

With regard to other microalgae species belonging to the genusChlamydomonas, Kobayashi et al. [29] observed that PCs were obviously detected in C. reinhardtii $3 \mathrm{~h}$ after the addition of 5.6 to $11.25 \mathrm{mg} \mathrm{Cd} / \mathrm{L}$, whereas they were not found in the presence 
of $1.12 \mathrm{mg} \mathrm{Cd} / \mathrm{L}$ even after $6 \mathrm{~h}$. However, in the present study an increase in the levels of PCs was detected, even in C. moewusii cells exposed to $1 \mathrm{mg} \mathrm{Cd} / \mathrm{L}$, although this observation was obtained $96 \mathrm{~h}$ after the addition of $\mathrm{Cd}$ to culture medium. Kahoko et al. [36] even confirmed different subtypes of PCs, from $\mathrm{PC}_{2}$ to $\mathrm{PC}_{6}$, in cultures with only $0.0067 \mathrm{mg} \mathrm{Cd} / \mathrm{L}$ and after $96 \mathrm{~h}$ of exposure, in the strains of $C$. acidophila KT1, C. acidophila DVB238 and C. reinhardtii C-9. They observed that $C$. acidophila KT1 and $C$. reinhardtii C-9 mainly synthesized $\mathrm{PC}_{2}$, which is also the most synthesized $\mathrm{PC}$ by C. moewusii in the present study (Fig. 4). These authors assumed that PCs play an important role in $\mathrm{Cd}$ tolerance in Chlamydomonas strains. This statement is also confirmed by the results obtained with $C$. moewusii.

Phytochelatins are rich in cysteine, and therefore their biosynthesis requires large amounts of this amino acid. Thus, tolerant microalgae should have a higher capacity to absorb, reduce and assimilate sulfate. Pérez-Rama et al. 3found that in the marine microalga Tetraselmis suecica, the amino acid cysteine exceeded in all cultures the concentration reached in controls. The amount reached by this amino acid was higher at the higher $\mathrm{Cd}^{2+}$ concentrations (15 and $30 \mathrm{mg} / \mathrm{L}$ ), after $7 \mathrm{~d}$ of exposure. In the present study, the cysteine concentration also increased with the exposure of $C$. moewusii to $\mathrm{Cd}^{2+}$, reaching the highest level at $8 \mathrm{mg} \mathrm{Cd} / \mathrm{L}$. Thus, as it happened with PCs, this amino acid also increased its level until the $\mathrm{Cd}^{2+}$ concentration that is near the EC50 value. But contrary to the PCs, the amount of cysteine remains stable at higher $\mathrm{Cd}^{2+}$ concentrations. Therefore, it acts as an important mechanism of defense to the metal in those cultures of 4,6 and $8 \mathrm{mg} \mathrm{Cd} / \mathrm{L}$, in which a decrease in the levels of PCs was observed. This observation could suggest that sulfate reduction is a very robust pathway able to support high cysteine demand, even in circumstances, as those of the present study withC. moewusii, in which the cysteine increase significantly when the microalga is exposed to high $\mathrm{Cd}^{2+}$ concentrations (Fig. 3). Quite the opposite of these results, Mendoza-Cózatl et al. [37] found no significant differences in the cysteine content in live sheaths of plants among the different $\mathrm{Cd}^{2+}$ exposure treatments.

Kaplan et al. [26] observed that, as a response to GSH addition to cultures ofChorella sp. cells exposed to $\mathrm{Cd}^{2+}$, there was an increase in the abundance of PCs. There are previous reports showing that GSH attenuates the inhibitory effect of $\mathrm{Cd}^{2+}$ in tomato cell cultures [38]. Nishikawa et al. [39] observed, using different strains of Chlamydomonas acidophila, that the PC content did not correlate closely with the level of $\mathrm{Cd}$ accumulation. They suggest that maintenance of a high GSH level seems to be more important for $\mathrm{Cd}$ accumulation. In the present study with $C$. moewusii, after $96 \mathrm{~h}$ of culture, significant differences were observed in the GSH levels among the $\mathrm{Cd}^{2+}$ concentrations assayed. GSH reached its maximum value at the $\mathrm{Cd}^{2+}$ concentration of $1 \mathrm{mg} / \mathrm{L}$ (below the EC50) and it begins to decrease gradually as the metal 
concentration increases, until $8 \mathrm{mg} \mathrm{Cd} / \mathrm{L}$. In the highest $\mathrm{Cd}^{2+}$ concentration $(10 \mathrm{mg} / \mathrm{L})$, where the toxicity of $\mathrm{Cd}$ is very evident, it was not detected (Fig. 3). Furthermore, these levels are correlated with those obtained for the PCs (Fig. 4). The levels of PCs are not only dependent on the activity of PC synthase but also on the amount of the substrate GSH. In C. moewusii, GSH levels did not decrease while PC levels increased. This behavior of the GSH is precisely due to that it acts as the main precursor molecule for the biosynthesis of the PCs, whose levels also decreased as $\mathrm{Cd}^{2+}$ concentration increased (Fig. 4).

Finally, the other important molecule in the synthetic pathway of PCs is $\gamma$-Glu-Cys. The $\gamma$-Glu-Cys content observed did not change significantly among the $\mathrm{Cd}^{2+}$ concentrations assayed and with respect to the control cultures (Fig. 4). The amount of $\gamma$-Glu-Cys remained quite stable and was very low, compared with that of cysteine. This seems to indicate that the activity of $\gamma$-Glu-Cys synthetase did not increase greatly because of $\mathrm{Cd}$ exposure. Similar observations were also obtained in the marine microalga T. suecica [21].

\section{CONCLUSIONS}

In the present study, it can be concluded that $\mathrm{Cd}$ has a toxic effect on the growth of Chlamydomonas moewusii. However, in the group of freshwater microalgae, $C$. moewusii is one of the most tolerant species to $\mathrm{Cd}$, since it possesses a high value of EC50 ( $4.1 \pm 0.8 \mathrm{mg} \mathrm{Cd} / \mathrm{L}$ at $96 \mathrm{~h}$ of exposure). The complete inhibition of its growth was reached in the cultures exposed to a high $\mathrm{Cd}^{2+}$ concentration $(8 \mathrm{mg} / \mathrm{L})$. There was an important synthesis of the amino acid cysteine, dependent on the $\mathrm{Cd}^{2+}$ concentration assayed, reaching its maximum level in the cultures exposed to 4 and $8 \mathrm{mg} \mathrm{Cd} / \mathrm{L}$. This amino acid remained with higher levels in those cultures in which a decrease in the concentration of PCs was observed. The concentrations of GSH and $\gamma$-Glu-Cys observed were much lower than that reached by the cysteine. A significant decrease in the GSH levels was observed as the $\mathrm{Cd}^{2+}$ concentration increased from $1 \mathrm{mg} / \mathrm{L}$, whereas $\gamma$-Glu-Cys did not show significant variations among the $\mathrm{Cd}^{2+}$ concentrations tested.

The production of PCs of 2 and 3 subunits was observed in the cultures exposed to $\mathrm{Cd}^{2+}$ until a concentration of $8 \mathrm{mg} / \mathrm{L}$ of this metal. The maximum value of both PCs was reached in the cultures exposed to $2 \mathrm{mg} \mathrm{Cd} / \mathrm{L}$, being much higher the concentration observed of $\mathrm{PC}_{2}$. Phytochelatins of 4 subunits were also detected, but only in the cultures exposed to 1 and $2 \mathrm{mg} \mathrm{Cd} / \mathrm{L}$, and their concentrations were very low in comparison with $\mathrm{PC}_{2}$ and $\mathrm{PC}_{3}$. $\mathrm{PCs}$ were not detected in the cultures without $\mathrm{Cd}^{2+}$ (controls). 
Because of its high tolerance to $\mathrm{Cd}$ and its ability to synthesize PCs in the presence of the metal, it could be concluded that $C$. moewusii is a good candidate, among freshwater microalgae, to be used in bioremediation processes. This would be useful information in practical applications such as phytoremediation of waters polluted by $\mathrm{Cd}$, and it could contribute to developing new techniques to deal with the problem of metal toxicity in the environment.

\section{Acknowledgements}

Cristina Suárez Díaz holds a Fellowship Award from the Xunta de Galicia.

\section{REFERENCES}

1. De la Noue J, De Paw N. 1998. The potential of microalgal biotechnology: A review of production and uses of microalgae. Biotechnol Adv 6: 725-770.

2. Mislin H, Ravera O. 1986. Cadmium in the Environment. Vol 50. Birkhäuser Verlag Basel, Basel, Switzerland.

3. Pérez-Rama M, Torres E, Abalde J. 2006. Composition and production of thiol constituents induced by cadmium in the marine microalga Tetraselmis suecica.Environ Toxicol Chem 25: 128-136.

4. Cobbett C. 2000. Phytochelatins and their role in heavy metal detoxification. Plant Physiol 123: 825-833.

5. Zenk MH. 1996. Heavy metal detoxification in higher plants - a review. Gene 179:21-30.

6. Ahner BA, Wei L, Oleson JR, Nori O. 2002. Glutathione and other low-molecular-weight thiols in marine phytoplankton under metal stress. Mar Ecol Prog Ser 232: 93-103.

7. Tsuji N, Nishikori S, Iwabe O, Shiraki K, Miyasaka H, Takagi M, Hirata K, Miyamoto K.2004. Characterzation of phytochelatin synthase-like protein encoded by alr0975 from a prokaryote, Nostoc sp. PCC7120. Biochem Biophys Res Commun 315: 751-755.

8. Ha S-B, Smith AP, Howden R, Dietrich WM, Bugg S. 1999. Phytochelatin synthase genes from Arabidopsis and the yeast, Schizosaccharomyces pombe. Plant Cell 11:1153-1164.

9. Mason AZ, Jenkins KD. 1995. Metal detoxification in aquatic organisms. In TessierA,TurnerDR, eds Metal Speciation and Bioavailability in Aquatic Systems. John Wiley \& Sons, Chichester, UK, pp 479-608.

10. Mutoh N, Hayashi Y. 1988. Isolation of mutants of Schizosaccharomyces pombe.Biochem Biophys Res Commun 151: 32-39.

11. Mehra RK, Mulchandani P, Hunter TC. 1994. Role of CdS quantum crystallites in cadmium resistance in Candida Glabrata. Biochem Biophys Res Commun 200:1193-1200. 
12. Grill E, Winnacker E-L, Zenk MH. 1985. Phytochelatins: the principal heavy-metal complexing peptides of higher plants. Science 230: 674-676.

13. Nagalakshmi N, Prasad MNV. 2001. Responses of glutathione cycle enzymes and glutathione metabolism to copper stress in Scenedesmus bijugatus. Plant Sci 160:291-299.

14. Tsuji N, Hirayanagi N, Okada M, Miyasaka H, Hirata $\quad \mathrm{K}$, Zenk $\mathrm{MH}$, Miyamoto K. 2002.Enhancement of tolerance to heavy metals and oxidative stress in Dunaliella tertiolecta by $\mathrm{Zn}$-induced phytochelatin synthesis. Biochem Biophys Res Commun 293:653659.

15. Tripathi BN, Gaur JP. 2006. Physiological behavior of Scenedesmus sp. during exposure to elevated levels of $\mathrm{Cu}$ and $\mathrm{Zn}$ and after withdrawal of metal stress.Protoplasma 229: 1-9.

16. Prado R, García R, Rioboo C, Herrero C, Abalde J, Cid A. 2009. Comparison of the sensivity of different toxicity test endpoints in a microalga exposed to the herbicide paraquat. Environ Int 35: 240-247.

17. 17Brown TE, Richardson FL, Vaughn ML. 1967. Development of red pigmentation in Chlorococcum wimmeri (Chlorophyta: Chlorococcales). Phycologia 6: 167-184.

18. Organization for Economic Cooperation and Development. 2006. Freshwater Algae and Cyanobacteria, Growth Inhibition Test. OECD Guidelines for the Testing of Chemicals. Vol 201. Geneva, Switzerland.

19. Pérez-Rama M, Torres E, Abalde J. 2005. Capillary zone electrophoresis for analysis of phytochelatins and other thiol peptides in complex biological samples derivatized with monobromobimane. Electrophoresis 26: 610-620.

20. Okamoto OK, Asana CS, AIdar E, Colepicolo P. 1996. Effects of cadmium on growth and superoxide dismutase activity of the marine microalga Tetraselmis gracilis(Prasinophyceae). J Phycol 32: 74-79.

21. Pérez-Rama M, Abalde J, Herrero C, Torres E. 2002. Cadmium removal by living cells of the marine microalga Tetraselmis suecica. Bioresour Technol 84: 265-270.

22. Folgar S, Torres E, Pérez-Rama M, Cid A, Herrero C, Abalde J. 2009. Dunaliella salina as a marine microalga highly tolerant to but a poor remover of cadmium. $J$ Hazard Mater165: 486-493.

23. Visviki I, Rachlin D. 1994. Acute and chronic effect exposure of Dunaliella salina and Chlamydomonas bullosa to copper and cadmium: effects on ultraestructure. Arch Environ Contam Toxicol 26: 154-162.

24. Rachlin JW, Warkentine BE, Jensen TE. 1982. The growth responses of Chorella saccharophila, Navicula inserta and Nitzschia clorsterium to selected concentrations of cadmium. Bull Torrey Bot Club 109: 129-135.

25. Yap CK, Isamail A, Omar $\mathrm{H}$, Tan SG. 2004. Toxicities and tolerances of $\mathrm{Cd}, \mathrm{Cu}, \mathrm{Pb}$ and $\mathrm{Zn}$ in a primary producer (Isochrysis galbana) and in a primary consumer (Perna viridis). Environ Int 29: 1097-1104. 
26. Kaplan D, Heimer YM, Abeliovich A, Goldsbrough PB. 1995. Cadmium toxicity and resistance in Chlorella sp. Plant Science 109: 129-137.

27. Le Faucheur S, Behra R, Sigg L. 2005. Phytochelatin induction, cadmium accumulation, and algal sensitivity to free cadmium ion in Scenedesmus vacuolatus. Environ Toxicol Chem 24: 1731-1737.

28. Mosulen S, Dominguez MJ, Vigara J, Vilchez C, Guiraum A, Vega JM. 2003. Metal toxicity in Chlamydomonas reinhardtii. Effect on sulfate and nitrate assimilation. Biomol Eng20: 199-203.

29. Kobayashi I, Fujiwara S, Saegusa H, Inouhe M, Matsumoto H, Tsuzuki M. 2005. Relief of arsenate toxicity by Cd-stimulated phytochelatin synthesis in the green alga Chlamydomonas reinhardtii. Mar Biotechnol 8: 94-101.

30. Tüzün I, Bayramoĝlu G, Yalçin E, Başaran G, Çelik G, Arica Y. 2005. Equilibrium and kinetic studies on biosorption of $\mathrm{Hg}(\mathrm{II}), \mathrm{Cd}(\mathrm{II})$ and $\mathrm{Pb}(\mathrm{II})$ ions onto microalgae Chlamydomonas reinhardtii. J Environ Manage 77: 85-92.

31. Rauser WE. 1990. Phytochelatins. Annu Rev Biochem 59: 61-86.

32. Alvarez-Lagorreta T, Mendoza-Cózatl DG, Moreno-Sánchez R, Gold-Bouchot G. 2008.Thiol peptides induction in the seagrass Thalassia testudinum (Banks ex König) in response to cadmium exposure. Aquat Toxicol 86: 12-19.

33. $\mathrm{Hu}$ S, Lau KWK, Wu M. 2001. Cadmium sequestration in Chlamydomonas reinhardtii. Plant Sci 161: 987-996.

34. Pérez-Rama M, Herrero C, Abalde J, Torres E. 2001. Class III metallothioneins in response to cadmium toxicity in the marine microalga Tetraselmis suecica (Kylin) Butch. Environ Toxicol Chem 20: 2061-2066.

35. Torres E, Cid A, Herrero C, Abalde J. 1998. Removal of cadmium ions by the marine diatom Phaeodactylum tricornutum Bohlin accumulation and long-term kinetics of uptake. Biores Technol 63: 213-220.

36. Kahoko N, Onodera A, Tominaga N. 2006. Phytochelatins do not correlate with the level of Cd accumulation in Chlamydomonas spp. Chemosphere 63: 1553-1559.

37. Mendoza-Cózatl DG, Loza-Tavera H, Hernández-Navarro A, Moreno-Sánchez R. 2005.Sulfur assimilation and gluthatione metabolism under cadmium stress in yeast, protists and plants. FEMS Microbiol Rev 29: 653-671.

38. Mendum SC, Gupta SC, Goldsbrough P. 1990. Effect of gluthatione on phytochelatin synthesis in tomato cells. Plant Physiol 93: 484-488.

39. Nishikawa K, Onodera A, Tominaga N. 2005. Phytochelatins do not correlate with the level of Cd accumulation in Chlamydomonas spp. Chemosphere 63: 1553-1559. 